AL MURABBI: Jurnal Pendidikan Agama Islam

P-ISSN (cetak) : 2086-9932

E-ISSN (online) : 2502-616X
Program Studi Pendidikan Agama Islam https://jurnal.yudharta.ac.id/v2/index.php/pai

Volume 5 Nomor 1 Desember 2019

\title{
IMPLEMENTASI NILAI-NILAI MULTIKULTURAL DI UNIVERSITAS YUDHARTA PASURUAN
}

\author{
Jamhuri \\ Universitas Yudharta Pasuruan \\ hm.jamhuri@yudharta.ac.id
}

\begin{abstract}
The multicultural theory according to Azyumardi Azra is one of the fundamental virtues of democracy, but it has an ambivalent power that is termanivestated in two forms; form of solid and democratic forms. Being

Received: Agustus $19^{\text {th }} 2019$

Revised:

November $19^{\text {th }} 2019$

Accepted:

December $16^{\text {th }} 2019$ tolerant is letting or allowing others to be themselves, respecting others, by appreciating their origins and background. The design that researchers use is a type of qualitative research with phenomenological design. Evidence of the social turbulence of intolerance occurring in Depok and Surabaya of East Java and Indonesia, such as radicalism, terrorist groups that often impose the will in instilling an idea against others, often Riots as the case occurred on Tuesday at. 22. Wib, 08 may 2018, about the Perlawana and seizery of police weapons owned by terrorists and murder of 4 police officers in sadistic, and The greeting of a police officer by NAPI terrorism which took place in Rutan Mako Brimob, Kelapa Dua, Depok Jawa Barat. And simultaneous bombardment in one day, on Sunday 13 May 2018 in three Greja in Surabaya namely: a) the Church of Santa Maria, Ngagel Surabaya. b) Christian Greja Indonesia Jl. Diponegoro Surabaya. c) Pentecostal Church, Jl. Arjuno Surabaya, and the night there is another bombing in Rusunawa, Jl. Along near Polsek Taman, Sidoarjo. And the next day on May 14, 2018 there was another bombing in Surabaya. On Wednesday, May 16, 2018 occurred again in Rian Mapolda, namely the white Mubil of police officers but the motorist fought and crashed the police, and police passed away, and the perpetrator also announced in Kompas TV Designated as terrorists. It is necessary to further increase the ideals of Romo Kyai Sholeh Babrudin: To create a campus that is tolerant, cool, peaceful, harmonious, mutual respect for each other and respect each other The difference is that they are a manifestation of the sublime value of multiculturalism
\end{abstract}

\section{Keywords: Implementation, Multicultural Values}

\section{PENDAHULUAN}

Secara umum yang kita Fahami Multikultural adalah suatu sikap yang menghargai atau menghormati orang lain, baik dalam suatu kelompok atau pun individu. Sikap menghargai bisa dari menghargai pendapat orang lain, agama orang lain serta menghargai keputusan orang lain dalam memilih keputusannya tersebut. Maka dari itu kami akan membahas Multikultural yang menonjol di lingkungan universitas yudharta pasuruan karena Universitas Yudharta Pasuruan telah berkomitmen untuk selalu bersikap toleransi, saling menghormati, selalu menghargai perbedaan dari kemajmukan masyarakat dari Sabang sampai Meraoke.

Multikultural yang sangat menonjol bisa dilihat dari Karyawan Universitas Yudharta pasuruan, yaitu sebagian kecil pegawai atau dosen serata mahasiswa terdiri dari non muslim, padahal Universitas Yudharta Pasuruan merupakan lingkungan pesantren akan tetapi meskipun dalam lingkungan Pesantren Universitas Yudharta lebih mengutamakan multicultural dan toleransi antar umat beragama, selalu 
menghargai perbedaan, tanpa memandang agama apa yang mereka anut, yang menganggap kita semua adalah saudara jadi harus saling menghargai dan menghormati antara umat beragama maupun dari perbedaan ras, suku, warna kulit dan adat istiadat dalam bermasyarakat.

\section{METODE}

Pendekatan yang peneliti gunakan adalah jenis penelitian kualitatif dengan pendekatan fenomenologi. Yaitu Desain penelitian,yang rencana dan struktur penelitian dibuat sedemikian rupa berdasarkan fenomena yang terjadi, sehingga dapat diperoleh jawaban atas pertanyaan-pertanyaan dalam penelitian, dari masing-masing individu memberikan jawaban dari setiap kasus atau pengalaman yang mereka ketahui terkait dengan pertanyaan tersebut diatas. Peneliti tidak hanya mendeskripsikan makna pengalaman informan penelitian, tetapi juga melakukan interpretasi terhadap pengalaman tersebut. Oleh karena itu peneliti lakukan secara intensif, terperinci dan mendalam terhadap individu, lembaga, kelompok dan lain sebagainya. Karena penelitian dilaksanakan Universitas Yudharta Pasuruan, maka Peneliti terlebih dahulu mengamati serta mendalami dan mengadakan pendekatan terhadap beberapa informan yang peneliti anggap membidangi tentang Multikultural.

\section{Gambaran Umum Subyek Penelitian}

Universitas Yudharta pasuruan didirikan di Pasuruan Jawa Timur pada tanggal 1 Agustus 2002 berdasarkan surat keputusan Mentri Pendidikan Nasional melalui Dirjen Dikti Nomor: 146/D/0/2002, kemudian diperbaharui dengan surat keputusan Mentri Pendidikan Nasional melalui Dirjen Dikti Nomor: 919/D/T/2005 s.d Nomor: 929/D/T/2005.

Universitas Yudharta Pasuruan merupakan salah satu kampus multicultural yang ada di pasuruan, Universitas yudharta berada di naungan yayasan Darut Taqwa yang di pimpin oleh KH. M. Sholeh Bahrudin. Universitas Yudharta Pasuruan mengedepankan multikulturalisme., Universitas Yudharta Pasuruan memiliki 5 Fakultas dan memiliki 15 jurusan untuk Strata 1 dan 1 jurusan untuk Pasca Sarjana (Strata 2) yakni PAI Multikultural.

\section{Kajian Teori Nilai Multikultural Sebagai Tolak ukur Keberhasilan Solidaritas Sivitas Akademika Universitas Yudharta Pasuruan}

Sebagian dari nilai multikulturan adalah nilai Toleransi, menghargai perbedaan, kebersamaan, tolong menolong, Positive thinking dan lain sebagainya. Dibawah ini saya kemukakan beberapa pendapat/ teori dari berbagai para pakar yang diperkuat oleh ayat al-Qur'an dan hasil penelitian sebagai berikut:

KH.Muhammad Tholchah Hasan dalam bukunya" Pendidikan multikultural sebagai opsi penanggulangan radikalisme" mengatakan: Multikulturalisme merupakan realitas kehidupan masyarakat dan bangsa, meski tidak setiap subyek masyarakat atau bangsa ini mau mengakui dan menerimanya. Selain itu multikulturalisme ini juga mengalami dinamika sesuiai dengan tingkat aktifitas upaya atau prestasi yang ditunjukkan masyarakat atau bangsa itu.

Suparlan mengutip Fay(1996) jary dan jary (1991) Watson (2000) dan Reed(1997) dalam buku KH. Muhammad Tholchah Hasan, ( 2016:10), menyebutkan bahwa multikulturalisme ini akan menjadi acuan atau referensi utama bagi terwujudnya masyarakat multikultural, karena multikulturalisme sebagai sebuah kesederajatan baik secara indifidual maupun secara kultural atau kelompok. Dalam kelompok sosial sekecil apapun kelompok ini jika direflesi dan dibaca dengan nalar yang obyektif, maka multikultural akan diakuinya sebagai realitas termasuk kehadiran model-modelnya.

KH. Muhammad Tholchah Hasan mengutarakan tentang pentingnya nilai toleransi, inklusif, kasih sayang, dan menghargai perbedaan atau At-Tasamuh (toleran) menjadi salah satu sikap dasar dan 
karakter ajaran Islam, sehingga Islam disebut sebagai agama kasih sayang. Hubungan orang Islam dengan non muslim terjalin dengan baik. (Hasan: 2016-66).

Ali Maksum berpendapat dalam bukunya "Pluralisme Multikulturalisme Paradigma Baru Pendidikan agama Islam di Indonesia" Terkait dengan pluralismeagama sikaptoleransi sebagai sikap hidup dalam menjaga kerukunan antarumat beragama. Kalau pluralisme lebih menekankan kepada pengakuan akan adanya perbedaan dan kesediaan mengakui kebenaran agama lain, maka dalam toleransi menekankan pada sikap saling menghormati dan menghargai antar umat beragama sehingga tercipta adat dan tatacara pergaulan yang harmonis antara berbagai kelompok yang berbeda-beda dalam pergaulan sehari-hari (Maksum,2011:134)

Teori Toleransi menurut Azyumardi Azra merupakan salah satu kebajikan fundamental demokrasi, namun ia memiliki kekuatan ambivalen yang termanivestasi dalam dua bentuk; bentuk solid dan bentuk demokratis. Menjadi toleran adalah membiarkan atau membolehkan orang lain menjadi diri mereka sendiri, menghargai orang lain, dengan menghargai asal-usul dan latar belakang mereka. Toleransi mengundang dialog untuk mengkomunikasikan adanya saling pengakuan. Hakikat toleransi pada intinya adalah usaha kebaikan, khususnya pada kemajemukan agama yang memiliki tujuan luhur yaitu tercapainya kerukunan, baik intern agama maupun antar agama (Azra,2003: 194).

H.Susari berpendapat dalam bukunya "Pendidikan agama Islam dalam perspektif Multikulturalisme" Secara konseptual toleransi artinya sikap hormat menghormati antar pemelukagama dan penganut kepercayaan yang berbeda-beda, dan menghindari diri dari sikap melemahkan orang lain karena agama, suku, ras atau faktor lain.(H. Susari, 2012:59)

Abd al-Karim al-Khotib dalam H. Susari, 2012,51. Menegaskan bahwa: Penanaman sikap penghargaan dan toleransi terhadap kelompok lain dalam perspektif ajaran Islam setidaknya didasarkan pada empat alasan, yaitu: 1) Manusia memiliki kedudukan yang mulia, apapun agama, kebangsaan, warna kulit, dan latar belakangnya. 2) Perbedaan agama merupakan kehendak Alloh sebagai konsekuensi dari kebebasan ikhtiar manusia. 3) Persoalan hisab atas kekhilafan dan hukuman atas kesesatan merupakan hak penuh Alloh, sehingga tidak ada alasan untuk mempertentangkan. 4) Akhlak muslim memerintahkan berlaku adil dan membenci kedzaliman kepada siapapun. Atas dasar ini maka tidak ada alasan bagi umat Islam untuk berprasangka kepada kelompok lain yang berbeda dan harus dikembangkan sikap positif terhadap adanya perbedaan,baik perbedaan atas latar belakang agama, suku, golongan, sosial dan ekonomi. ( H. Susari,2012,51.)

Beberapa ahli sudah menempatkan multikultural sebagai model, artinya dalam model multikulturalisme ini, sebuah masyarakat termasuk juga masyarakat Indonesia atau masyarakat manapun dimuka bumi ini, hususnya yang kondisinya seperti Indonesia, mempunyai sebuah kultur yang berlaku general dalam masyarakat yang coraknya seperti suatu mosaik. Dilalam mosaik itu tercakup semua kebudayaan dari masyarakat-masyarakat yang lebih kecil yang membentuk terwujudnta masyarakat yang lebih besar, yang mempunyai kultur seperti sebuah mosaik, multikulturalisme diperlukan dalam bentuk konstruksikehidupan masyarakat dan bangsa sehingga terwujud keharmonisan dalam keragaman kultural atau berbudaya dalam realitas keragaman.

Sesesungguhnya toleransi merupakan salah satu diantara sekian ajaran inti dari Islam. Toleransi sejajar dengan ajaran fundamental yang lain, seperti kasih sayang (rahmah) kebijaksanaan atau hikmah, kemaslahatan universal (al-Maslahah al-ammah), dan keadilan. Hal ini dijelaskan Alloh dalam al-Qur'an Surat al-Kafirun: 


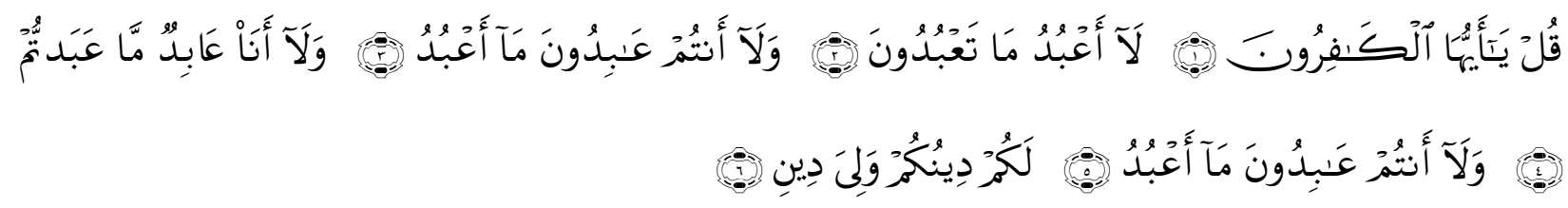

1. Katakanlah: "Hai orang-orang kafir,

2. aku tidak akan menyembah apa yang kamu sembah.

3. dan kamu bukan penyembah Tuhan yang aku sembah.

4. dan aku tidak pernah menjadi penyembah apa yang kamu sembah,

5. dan kamu tidak pernah (pula) menjadi penyembah Tuhan yang aku sembah.

6. untukmu agamamu, dan untukkulah, agamaku.(Add-Ins/al-Qur'an Digital)

Ayat di atas berisi tentang pengakuan terhadap esensi agama lain, dalam sejarah tidak hanya Adam dan Hawa yang diminta turun kebumi, tetapi juga Iblis. Hal ini berati yang berhak hidup dibumi ini tidak hanya kebenaran, tetapi juga kejahatan, karena Iblis yang merupakan simbul kejahatan dijamin hak hidupnya oleh Alloh sampai hari akhir. Oleh karena itu kekerasan atau pemaksaan terhadap manusia untukmengikuti kehendaknya tidak dibenarkan oleh Islam. Dari sini sikap toleransi harus dikembangkan untuk menciptakan suasana yang harmoni dalam kehidupan masyarakat. .(H. Susari, 2012:60)

Bekerjasama dengan pihak non muslim itu ada dua macam. Pertama, tidak berhubungan dengan ritual keagamaan. Kedua, berhubungan dengan urusan agama.

1) Tidak berhubungan dengan urusan ritual keagamaan.

Masa kehidupan Nabi Muhammad SAW banyak sekali bermuamalah dengan non muslim, dalam arti berdagang, atau usaha usaha tertentu. Karena muamalah itu tidak terkait dengan urusan ritual keagamaan, maka hal itu dibenarkan. Misalnya ketika Nabi Muhammad SAW masih di Mekkah, orangorang non muslim yang memusuhi beliau itu, bahkan malah banyak menitipkan harta mereka kepada Rasulullah SAW, sebagai amanah atau barang titipan, Rosulullah tetap menerima dengan lapang dada, dengan sifat serta sikap amanah yang beliau pegang teguh, maka Rosululloh diberi gelar gelar al-Amin oleh Non muslim saat itu, karena dalah hati besar mereka mengakui bahwa Rosulullohlah yang sangat wajar untuk diberi gelar al-Amin tersebut diatas, dan Non muslim termasuk kedua pamannya sendiri yaitu Abu Tholib dan Abu Lahab pada saat itu tidak pernah mencabut gelar al-Amin yang mereka sandangkan pada Rosululloh tersebut. Oleh sebab itulah ketika Rasulullah SAW akhirnya hijrah ke Madinah, beliau masih banyak mengemban amanah yang berupa harta titipan milik orang-orang non muslim yang harus dikembalikan terlebih dahulu kepada pemiliknya. Dalam perjalanan hijrah pun, Rasulullah SAW tetap bermualamah dengan orang kafir. Beliau dan Abu Bakar menyewa penunjuk jalan profesional, Abdullah bin Uraiqidzh, yang saat itu bukan orang Islam, untuk mengantarkan mereka berdua hingga tiba ke kota Madinah. Sesampai di Madinah, ternyata Rasulullah SAW ketepatan bertetangga dengan orang Yahudi. Bahkan ketika kehabisan makanan, beliau SAW menggadaikan baju besinya kepada tetangga Yahudi tersebut, untuk mendapatkan pinjaman.

Kebun kurma di Khaibar yang menjadi harta rampasan perang ketika berhasil mengalahkan pihak Yahudi, kemudian dikelola secara bagi hasil dengan petani kurma yang beragama Yahudi. Sebab mereka adalah petani kurma yang berpengalaman dan paling mengerti cara bertani. Kalau kita mau teruskan, maka masih ada banyak lagi bagaimana contoh muamalah Rasulullah SAW dengan pihak non muslim, yang tidak terkait dengan urusan agama, dan dalam Islam tidak ada larangan untuk melakukan muamalah dengan non muslim.. 
2) Berhubungan dengan Urusan Agama.

Adapun muamalah atau kerjasama yang berhubungan dengan urusan agama, bisa kita bagi tiga. Pertama, kerjasama/muamalah itu terkait kepentingan agama Islam. Kedua, kerjasama yang terkait dengan kepentingan bersama. Ketiga, kerjasama yang terkait dengan agama lain.

a) Kerjasama/muamalah yang berhubungan dengan kepentingan agama Islam.

Ketika umat Islam terdesak kebutuhan tertentu yang tidak bisa dipenuhi oleh sesama umat Islam sendiri, akan tetapi bisa memenuhinya justru harus kerjasama dengan pihak non muslim. Contoh yang paling mudah adalah urusan transpotasi haji. zaman nenek moyang kita, umat Islam di Indonesia pergi haji ke tanah suci menumpang kapal milik Belanda, sebelum memiliki kapal laut sendiri. Itu berarti umat Islam bermuamalah dengan non muslim, untuk kepentingan agama Islam, dan jama'ah hajji saat sekarang, P.T Garuda Indonesia tidak mencukupi untuk melayani jamaah haji, apalagi kuota jamaah hajji pada tahun 2017 ditambah oleh Presiden RI Joko Widodo setelah negosiasi dengan Raja Salman Arab Saudi, sehingga terpaksa sewa 20 pesawat dari banyak Negara, dimana perusahan pesawat tersebut non muslim. yang disewa sekalian dengan pilot dan awak kapalnya. Dan meski penerbangan pesawat yang isinya calon jamaah haji semua, tetapi pilot dan awak bawaan asli pesawat itu malah non muslim. Namun Garuda kemudian menambahi awak flight attenden dari pihak sendiri, khususnya mereka yang muslimah, bahkan berjibab, untuk menyesuaikan keadaan. Inilah contoh bagaimana muamalah dengan pihak non muslim yang berhubungan dengan agama Islam. Dan para ulama sepakat tentang kebolehan bermuamalah dengan non muslim.

b) Terkait Dengan Kepentingan Bersama

Alloh berfirman dalam surat al-an'am,108

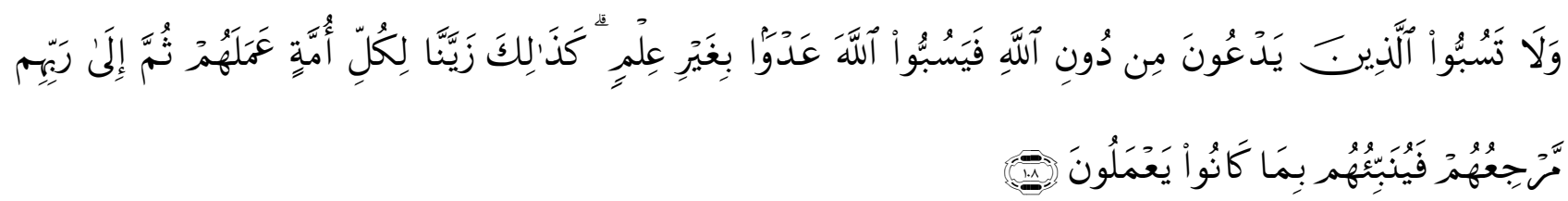

108. dan janganlah kamu memaki sembahan-sembahan yang mereka sembah selain Allah, karena mereka nanti akan memaki Allah dengan melampaui batas tanpa pengetahuan. Demikianlah Kami jadikan Setiap umat menganggap baik pekerjaan mereka. kemudian kepada Tuhan merekalah kembali mereka, lalu Dia memberitakan kepada mereka apa yang dahulu mereka kerjakan. (Add-Ins/ al-Qur'an Digital )

Ummat Islam dan Non Muslim di Indonesia harus hidup bersama, sehingga juga punya kepentingan yang sama, asalkan kepentingan bersama itu tidak merugikan agama kita, pada prinsipnya hidup berdampingan seperti di atas sangat diperlukan. Contoh yang nyata dalam hal ini adalah perjanjian atau Piagam Madinah yang ada di masa Rasulullah SAW. Esensi dari piagam itu adalah bahwa pihak Muslim dan pihak Yahudi bekerja sama dalam keamanan dalam negeri di Madinah. Bila pihak Muslim diperangi oleh suatu kaum, maka pihak Yahudi Madinah khususnya wajib ikut membela pihak Muslim. Sebaliknya, bila pihak Yahudi Madinah diperangi oleh pihak lain, maka umat Islam di Madinah wajib membela mereka.

Kalau kita perhatikan, salah satu isi dari perjanjian ini bahwa umat Islam wajib membela pihak Yahudi. Pasal ini menarik untuk diperhatikan, kok bisa ya umat Islam diwajibkan membela Yahudi, apa hal itu tidak bertentangan dengan prinsip aqidah kita? Jawabnya bahwa masalah ini tidak terkait dengan aqidah, tetapi terkait dengan muamalah dan kepentingan bersama dan kemanusiaan. Ketika seorang muslim membela tetangganya yang sedang diperangi oleh satu pihak, maka hal itu justru merupakan kebaikan. Asalkan titik permasalahannya bukan masalah aqidah atau ritual agama. 
Contoh Lain di Indonesia seperti jika terjadi bencana kemanusiaan semisal Tsunami di Aceh, pukul 7,59 waktu setempat, tanggal 26 Desember 2004, gempa berkekuatan 9,1 sampai 9,3 skala Richter, mengguncang dasar laut di barat daya Sumatra, sekitar 20 sampai $25 \mathrm{Km}$ lepas pantai. Perserikatan Bangsa-bangsa (PBB) menyatakan, Tsunami diAceh sebagai bencana kemanusiaan terbesar yang pernah terjadi. Bantuan Internasional mulai digerakkan menuju kawasan bencana di Aceh. Ternyata bantuan dari berbagai macam bentuk kebutuhan justru yang terbesar adalah dari kalangan Negara Non muslim, seperti Amerika, Australia, Inggris, Prancis, Jerman,Rusia dan lain sebagainya. Itu menunjukkan bahwa nilai toleransi atas dasar kemanusiaan adalah lebih tinggi dari pada yang lain.

c) Terkait Dengan Kepentingan Agama Lain

Bentuk yang ketiga adalah muamalah dengan pihak agama lain, khususnya untuk kepentingan ritual peribadatan agama mereka. Contohnya adalah seorang muslim bekerja dalam proyek pembangunan gereja, entah jadi tukang kayu, tukang batu, atau pun jadi arsitek yang membuat gambar rancangan desain gereja. Jumhur ulama, termasuk di dalamnya Mazhab Al-Hanafiyah, Al-Malikiyah, Asy-Syafi'iyah dan Al-Hanabilah satu kata, bahwa bekerja di gereja itu jelas-jelas disepakati keharamannya. Dasar keharamannya adalah cara itu termasuk ke dalam kategori membantu kemaksiatan. Karena dalam pandangan aqidah kita, ritual ibadah yang mereka lakukan itu setara dengan kemaksiatan, walau pun kita tidak boleh melarangnya. Allah SWT berfirman dalam Surat al-Maidah: 2

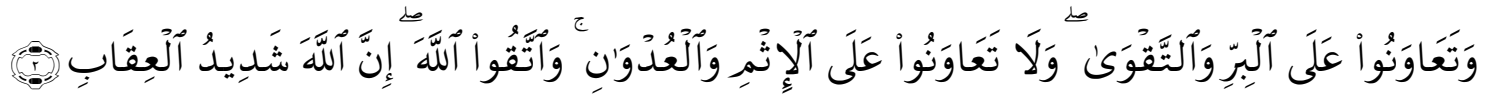

2. dan tolong-menolonglah kamu dalam (mengerjakan) kebajikan dan takwa, dan jangan tolongmenolong dalam berbuat dosa dan pelanggaran. dan bertakwalah kamu kepada Allah, Sesungguhnya Allah Amat berat siksa-Nya. ( Add-Ins/ al-Qur'an Digital).

Dalam realitas kehidupan nyata, bagaimana penerapan ketentuan hukum di atas, khususnya di masa kita sekarang ini? Jawabannya tergantung posisi kita. Kalau posisi kita sebagai pengusaha atau pemilik perusahaan, maka sejak awal hukumnya haram untuk menerima order untuk membangun gereja, dan semua hal yang terkait dengan kepentingan langsung ritual agama mereka. Maka hukumnya haram menerima order untuk mencetak spanduk natalan, mencetak Bible atau Injil, menjahit baju para pendeta atau biarawati, merias acara natalan, menjadi MC atau menjadi penyanyi di gereja atau momen ritual agama. Juga termasuk diharamkan menyewakan sound system buat ritual agama, bahkan termasuk pesanan katering untuk upacara ritual keagamaan. Semua itu diharamkan, karena posisi kita adalah orang yang menentukan pilihan, dan kita punya banyak alternatif pilihan lain selain harus mengerjakan proyek gereja. Tetapi nanti hukumnya akan beda lagi bila posisi kita hanya sebagai karyawan, yang berada pada posisi tidak bisa menentukan jenis pekerjaan sendiri, kecuali dengan cara ditempatkan oleh perusahaan. Dalam posisi ini, kita tidak terlalu bisa untuk menentukan pilihan. Maka tekanan nilai keharamannya tentu berbeda dengan posisi sebagai pemilik perusahaan, meski tetap sama-sama haram hukumnya.

Jika dalam aspek sosial kemasyarakatan semangat Multikultural menjadi sebuah anjuran, umat Islam boleh tolong menolong, bekerja sama dan saling menghormati dengan orang-orang non Islam, tetapi dalam soal aqidah sama sekali tidak dibenarkan adanya toleransi (beragama) antara ummat Islam dengan orang-orang non Islam.

Rasulullah SAW tatkala diajak ber-toleransi dalam masalah aqidah, bahwa pihak kaum Muslimin mengikuti ibadah orang-orang kafir dan sebaliknya, orang-orang kafir juga mengikuti ibadah kaum Muslimin, secara tegas Rasulullah SAW diperintahkan oleh Allah SWT untuk menolak tawaran yang ingin menghancurkan prinsip dasar Aqidah Islamiyah itu. 
Demikian Juga KH. Muhammad Tholchah Hasan mengutarakan tentang pentingnya nilai toleransi, kasih sayang, dan menghargai perbedaan adalah: bahwa berbagai komflik sosial yang telah menimbulkan keterpurukan di negeri ini disebabkan oleh kurangnya kemauan untuk menerima dan menghargai perbedaan, ide dan pendapat orang lain,karya dan jerih payah orang lain, melindungi yang lemah dan tidak berdaya, menyayangi sesama, kurangnya kesetiakawanan sosial, dan tumbuhnya sikap egois serta kurang perasaan atau kepekaan sosial ( Hasan: 2016-19).

Indonesia mempunyai banyak suku, budaya dan adat istiadat yang berbeda di tiap-tiap daerah. Masyarakat yang berbeda-beda itu, tidak hanya ada di tempat kita bekerja, tapi juga ada di lembaga pendidikan atau perguruan tinggi. Perguruan tinggi sama halnya miniatur Indonesia. Mahasiswa dari belahan kota manapun, bisa kita temukan di perguruan tinggi. Dan didalam kampus inilah, mahasiswa yang beraneka ragam itu melakukan interaksi satu dengan yang lain. Mereka bukan hanya membahas berbagai mata kuliah, tapi juga membahas informasi-informasi dari luar melalui organisasi mahasiswa yang mereka ikuti di Universitas Yudharta.

Universitas Yudharta memang menjadi rumah kedua bagi mahasiswa. Karena itu Kampus Universitas Yudharta harus memberikan kedamaian, untuk mendukung semangat belajar mengajar. Kedamaian akan mampu menciptakan generasi yang tenang dan toleran. Seperti hal nya kampus yang menyandang "Multicultural University", yang mana nilai toleransinya sangat tinggi. Mahasiswa Universitas Yudharta juga pernah melakukan study banding di Universitas PETRA Surabaya yang mana Universitas tersebut adalah Universitas Kristen. Dengan kegiatan tersebutlah Universitas Yudharta tidak membeda bedakan agama untuk belajar. Dari situlah kita bisa melihat bahwa kita belajar tidak boleh memandang agama, ras, suku dan lain lain. Karena kita adalah negara yang mempunyai berbagai ras, suku dan agama. Dan disitulah kita bisa menikmati indahnya perbedaan.

\section{Bukti Autentik sikap Intoleran di beberapa Gereja di Surabaya.}

Sikap toleransi merupakan satu nilai dari beberapa nilai dari Multikulturalisme, yang hal ini di sebutkan dari beberapa ayat dalam al-Qur'an. Sebagaimana yang telah di amanatkan serta di cita-citakan oleh Romo Kyai Sholeh Bahrudin "Bahwa Pembentukan sikap multikulturalisme yang didalamnya ada nilai-nilai toleransi harus diterapkan di Universitas Yudharta Pasuruan, dan di Indonesia, melihat gejolak sosial yang terjadi di Surabaya jawa Timur dan Indonesia ahir-ahir ini seperti radikalisme, kelompok teroris yang sering memaksakan kehendak dalam menanamkan suatu ide terhadap orang lain, sering terjadinya kerusuhan sebagaimana kasus yang terjadi pada hari Selasa pukul.22.Wib, tanggal 08 Mei 2018, tentang perlawana dan perampasan beberapa senjata api milik kepolisian oleh napi Teroris dan pembunuhan terhadap 4 aparat kepolisian secara sadis, serta penyandraan seorang perwira kepolisian oleh Napi terorisme yang terjadi di Rutan Mako Brimob, Kelapa Dua, Depok Jawa Barat. Dan pengeboman - pengeboman serentak dalam satu hari, pada hari Minggu 13 Mei 2018 di tiga Greja di Surabaya yaitu: a) Greja Santa Maria, Ngagel Surabaya. b) Greja Kristen Indonesia Jl. Diponegoro Surabaya. c) Greja Pantekosta Jl. Arjuno Surabaya, dan malam harinya terjadi pengeboman lagi di Rusunawa, Jl. Sepanjang dekat Polsek Taman, Sidoarjo. Dan keesokan harinya pada tanggal 14 Mei 2018 terjadi pengeboman lagi di Polrestabes Surabaya. Hari Rabu tanggal 16 Mei 2018 terjadi penyerangan lagi di Mapolda Riau, yaitu mubil warna putih disetop aparat kepolisian tetapi pengendara mobil tersebut melawan dan menabrak polisi tersebut, dan polisi meninggal dunia, dan pelaku juga di umumkan di Kompas TV ditetapkan sebagai teroris. kiranya Kampus Universitas Yudharta Pasuruan sangat perlu sekali lebih meningkatkan lagi cita-cita dari Romo Kyai Sholeh Bahrudin yaitu: mewujudkan kampus yang penuh toleran,sejuk, damai, rukun, saling menghargai satu sama lain serta 
saling menghormati perbedaan dimana semua itu merupakan penjilmaan dari nilai luhur sikap multikulturalisme.

Sikap multikulturalisme adalah sikap yang dimiliki oleh para dosen, mahasiswa Universitas Yudharta Pasuruan, bahkan tidak hanya di kalangan kampus, lebih luas lagi bagi segenap masyarakat seluruh bangsa Indonesia, yang pada hakekatnya sikap multikulturalisme itu memang harus dimiliki oleh warga negara Indonesia, sehingga penting sekali semisal menerapkan mata kuliah Pendidikan Aswaja dan mata kuliah pendidikan dasar-dasar multikultural, di semua fakultas dan Jurusan, karena dalam kedua mata kuliah tersebut menerangkan tentang nilai-nilai sikap mltikulturalisme, sehingga nantinya tercapailah cita-cita pemerintah dalam membendung dan mencegah gejolak negatif radikalisme yang akan merusak tatanan Bhinneka Tunggal Ika”.

\section{PEMBAHASAN}

Hasil penelitian menunjukkan bahwa Nilai Multikultural memandang bahwa seharusnya setiap individu atau kelompok memiliki sikap saling menghargai. Mahasiswa Universitas Yudharta Pasuruan berasal dari berbagai Pulau, etnis, budaya, bahasa, namun perbedaan-perbedaan tersebut tidak menjadi penghalang dalam menjalankan pergaulan sehari-hari berlangsung akrab saling memahami dan menghargai, mampu berintraksi sosial sesuai dengan norma-norma yang ada ditengah-tengah masyarakat, mereka mampu menjunjung tinggi adat kebiasaan dan budaya. di Universitas Yudharta sangat ditanamkan sikap multikultural disetiap program studinya. Salah satunya terdapat di visi misi Universitas Yudharta, yakni kita dituntut untuk menjadi dosen dan mahasiswa yang bersikap multikulturalisme, berpikiran luas dalam menanggapi segala masalah, dan juga ketika terjun dimasyarakat dapat diterima dengan mudah. Multikulturalisme adalah pandangan seseorang yang dapat menerima adanya keragaman dimasyarakat menyangkut nilai-nilai, sistem, budaya, kebiasaan, dan politik yang di anut. Pada poin ini dosen sudah memiliki pandangan yang luas serta dapat menerima dan berperan terhadap keragaman dan toleran yang terdapat di Universitas Yudharta, baik agama, budaya, Juga adil ketika memberikan ilmu kepada mahasiswa tanpa membeda-bedakan satu sama lain.

Mahasiswa baru di Universitas Yudharta ini juga berasal dari berbagai daerah, mulai luar kota sampai luar jawa. Yang mana masing masing budaya di daerah masing masing berbeda, disitulah mahasiswa di Universitas Yudharta mulai belajar toleransi. Menjadi tugas kita untuk menjadikan kampus sebagai rumah toleransi. Karena yang belajar di kampus Universitas Yudharta berasal dari daerah yang berbeda, sudah semestinya mahasiswa, dosen, rektor dan pihak-pihak yang lain di Universitas Yudharta Pasuruan memberikan akses yang seluas-luasnya terhadap toleransi. Karena kampus merupakan tempat belajar yang efektif, maka belajarlah untuk saling bertoleransi di dalam kampus Universitas Yudharta. Dengan saling bertoleransi, secara tidak langsung kita telah membangun filter bagi lembaga pendidikan, untuk tidak mudah terpengaruh paham radikalisme. Kampus Universitas Yudharta juga harus lebih selektif lagi, ketika mendatangkan pihak-pihak luar ke dalam kampus. Karena kampus Universitas Yudharta menjadi tempat belajar untuk bertoleransi, maka kampus harus menjadi rumah damai bagi siapa saja. Kampus Universitas Yudharta harus bergerak membentuk karakter kebhinekaan. Dengan demikian, mahasiswa dan dosen yang berasal dari berbagai daerah itu, bisa saling berdampingan tanpa mempersoalkan perbedaan agama, suku, ras dan golongan.

Maka patut bersyukur dan bangga kita berada di Negara yang kaya dengan berbagai ragam budaya, ras, suku, agama, dimana mereka saling menghargai saling toleransi antara mereka, hal ini seperti yang di contohkan Romo Kyai Sholeh beliau mengajarkan kita untuk bersikap toleran beliau juga mencontohkan kepada kita bagaimana sikap toleran itu, beliau mengajarkan kepada kita untuk merangkul bukan memukul, mencari kawan bukan mencari lawan, mengajak bukan mengejek. Bahkan 
beliau juga sering mendapat undangan ke tempat ibadah agama lain, beliau sangat ramah terhadap non muslim, mereka pun juga sering datang ke Romo Kyai Sholeh, mereka suka dengan sikap Romo Kyai Sholeh yang menghargai perbedaan.

\section{PENUTUP}

Berdasarkan hasil pembahasan dan diskusi dan berbagai pendapat serta teori di atas, menunjukkan bahwa Nilai Multikultural di Universitas Yudharta setiap hari, sudah diterapkan, karena terlihat bahwa dari kalangan dosen, karyawan dan mahasiswa Universitas Yudharta, tejadi saling menghargai antara dosen, karyawan dan atau mahasiswa yang lain. Nilai multikultural mengakui terhadap pluralisme dalam suatu komunitas di Universitas Yudharta Pasuruan, mereka mengedepankan prinsip multikultural yang bermuara pada tumbuhnya kepekaan terhadap berbagai kemungkinan dari keunikan yang ada di Universitas Yudharta Pasuruan. Dalam konteks ini dimaksudkan bahwa mahasiswa, dosen, karyawan Universitas Yudharta Pasuruan, terbuka menerima serta menghargai dengan sikap toleransi, tolong menolong, selalu berfikir positif terhadap berbagai kemajmukan yang ada. Prinsip bersikap bersikap muncul karena mereka sama-sama memandang akan adanya kebutuhan kerjasama yang bersifat fondamintal, oleh karena itu saling menghargai orang lain itu adalah suatu sikap kemajmukan yang harus di pegang teguh, dan berdasarkan diskusi diatas nilai-nilai Multikultural sudah dilaksanakan dengan baik di Universitas Yudharta Pasuruan. Romo Kyai Sholeh bahrudin, beliau memiliki nilai toleransi yang sangat tinggi antar umat beragama, bisa dilihat waktu perayaan natal, Romo kyai Sholeh di undang untuk menghadiri perayaan natal. Dan beliau tidak melarang untuk menghadiri perayaan tersebut, bahkan Romo Yai Sholeh pernah diundang untuk meresmikan kembali gereja yang pernah dibakar oleh masyarakat dan beliau menghadiri. Bahkan Romo Yai Sholeh juga pernah di kunjungi tamu dari luar negeri dan sebagainya, walau meraka bukan dari kalangan muslim, namun Romo Yai Sholeh menyambut mereka dengan senang hati, beliau tidak berusaha merubah agama mereka, itu tandanya Romo Kyai Sholeh memiliki sikap Multikulturalisme yang sangat tinggi.

\section{DAFTAR PSUTAKA}

Add Ins/ al-Qur'an digital

Azra, Azyumardi. 2003. "Pendidikan Multikultural, membangun kembali Indonesia Bhinneka Tunggal Ika". Jakarta:Logos.

Departemen Agama.2002. al-Qur'an dan terjemahnya.

Hasan KH. Muhammad Tholchah ,2016, "Pendidikan Multikultural sebagai opsi penanggulangan Radikalisme". Malang:Lembaga Penerbitan Universitas Islam.

Hasan KH. Muhammad Tholchah,2013," Diskursus Islam Kontemporer",Jakarta Utara: PT. Listafariska Putra.

H.Susari,2012"Pendidikan agama Islam dalam perspektif Multikulturalisme” Tangerang: Selatan,YPM.

Maksum Ali,2011,"Pluralisme dan Mulikulturalisme Paradikma baru Pendidikan Agama Islam di Indonesia'Tlogo Mas Malang, Aditya Media Publisbing,

Moleong, Lexy. 2002.” Metodologi Penelitian Kualitatif”. Bandung”: Remaja Rosda Karya. 